\title{
A novel fluorescent molecule based on 1,8- naphthalimide: synthesis, spectral properties, and application in cell imaging
}

\author{
Haibo Xiao • Minjuan Chen • Guanghao Shi • \\ Lei Wang · Hongyao Yin $\cdot$ Chong Mei
}

Received: 28 June 2010/ Accepted: 14 October 2010/Published online: 23 November 2010

(C) The Author(s) 2010. This article is published with open access at Springerlink.com

\begin{abstract}
A novel naphthalimide molecule, 4-(2-methoxyethoxy)- $N$-butyl-1,8naphthalimide (MEBN), has been synthesized and characterized. The UV-visible absorption and fluorescence emission spectral properties in $n$-hexane, toluene, $\mathrm{CHCl}_{3}$, and $\mathrm{CH}_{3} \mathrm{OH}$ were studied. Its optical properties depend on solvent polarity. The application of MEBN in cell imaging was investigated.
\end{abstract}

Keywords 1,8-Naphthalimide · Fluorescence · Synthesis · Cell imaging

\section{Introduction}

Derivatives of 1,8-naphthalimide usually exhibit strong fluorescence. They have been widely used as colorants in the polymer industry, fluorescent probes for medical and biological purposes, and as n-type materials in organic light-emitting diodes [1]; they are potential anti-HIV drugs, fluorescent cell markers, DNAcleaving agents, liquid-crystal additives, and laser dyes [1].

The excellent fluorescent properties of commercial 1,8-naphthalimide compounds depend largely on the presence of strong electron-donating groups, typically such groups as alkoxy and alkylamine, at the C-4 position [2]. It is known that 4-alkoxy-1,8-naphthalimides have been widely used as fluorescent brightening agents. In this paper, a novel 4-alkoxy-1,8-naphthalimide compound, 4-(2-methoxyethoxy)$\mathrm{N}$-butyl-1,8-naphthalimide (MEBN) was prepared by a simple method. The UV-visible absorption and fluorescence emission spectral properties were studied. Application in cell imaging was investigated.

H. Xiao $(\bowtie) \cdot$ M. Chen · G. Shi · L. Wang $\cdot$ H. Yin · C. Mei

Department of Chemistry, Shanghai Normal University, 200234 Shanghai,

People's Republic of China

e-mail: xiaohb@shnu.edu.cn 


\section{Experimental}

Solvents and reagents were obtained from commercial sources. 1,8-Naphthalic anhydride was recrystallized from chlorobenzene before use. Other chemicals were analytical regents and used as received. Further purification and drying were employed by standard methods, and they were distilled before use when necessary. Melting points were determined with an XT4A apparatus and are uncorrected. Mass spectral studies were carried out using a VG12-250 mass spectrometer. ${ }^{1} \mathrm{H}$ NMR and ${ }^{13} \mathrm{C}$ NMR spectra were obtained on a Bruker DRX $400 \mathrm{MHz}$ spectrometer. Chemical shifts are reported in ppm relative to $\mathrm{Me}_{4} \mathrm{Si}$ as standard. Carbon, nitrogen, and hydrogen were determined on an Elementar Vario EL. Steady-state emission and excitation spectra were recorded on a Perkin-Elmer LS55 instrument. Visible absorption spectra were determined on a Perkin-Elmer Lambda 35 spectrophotometer. Cell images were acquired by use of a luminescence microscope.

Preparation of 4-bromo- $N$-butyl-1,8-naphthalimide

A mixture of 4-bromo- $N$-butyl-1,8-naphthalic anhydride $(5.0 \mathrm{~g}, 18 \mathrm{mmol})$, butylamine $(1.7 \mathrm{~g}, 23.3 \mathrm{mmol})$, and $50 \mathrm{~mL}$ acetic acid was heated under reflux for $3 \mathrm{~h}$ under nitrogen. After cooling, the mixture was dissolved in $100 \mathrm{~mL}$ water. The crude solid was further purified by recrystallization from alcohol and $5.0 \mathrm{~g}$ white solid was obtained, Yield 83.5\%. mp $109-110{ }^{\circ} \mathrm{C}$. ${ }^{1} \mathrm{H} \mathrm{NMR}\left(500 \mathrm{MHz}, \mathrm{CDCl}_{3}\right)$ : $\delta 8.68(\mathrm{~d}, J=7.2 \mathrm{~Hz}, 1 \mathrm{H}), 8.59(\mathrm{~d}, J=8.4 \mathrm{~Hz}, 1 \mathrm{H}), 8.43(\mathrm{~d}, J=7.6 \mathrm{~Hz}, 1 \mathrm{H})$, $8.06(\mathrm{~d}, J=8.0 \mathrm{~Hz}, 1 \mathrm{H}), 7.87(\mathrm{t}, J=7.2,7.2 \mathrm{~Hz}, 1 \mathrm{H}), 4.19(\mathrm{t}, J=7.6,7.6 \mathrm{~Hz}$, 2H), $1.73(\mathrm{~m}, 2 \mathrm{H}), 1.46(\mathrm{~m}, 2 \mathrm{H}), 1.00(\mathrm{t}, J=7.2,7.2 \mathrm{~Hz}, 3 \mathrm{H})$.

\section{Preparation of MEBN}

A 50-mL round-bottomed, one-necked flask was charged with $1.2 \mathrm{~g}$ (3.01 mmol) 4-bromo- $N$-butyl-1,8-naphthalimide, $4 \mathrm{~mL}$ 2-methoxyethanol, $0.096 \mathrm{~g} \quad(0.503$ $\mathrm{mmol}) \mathrm{CuI}$, and $1.96 \mathrm{~g}(20 \mathrm{mmol}) \mathrm{K}_{2} \mathrm{CO}_{3}$. The reaction mixture was heated under reflux for $3 \mathrm{~h}$. After cooling, the mixture was extracted with ethyl acetate and dried over $\mathrm{MgSO}_{4}$. The crude solid was further purified by silica gel column chromatography using petroleum ether and ethyl acetate $(5: 1, \mathrm{v} / \mathrm{v})$ as eluent to afford $1.1 \mathrm{~g}$ yellow solid, Yield 93\%. mp $103-105{ }^{\circ} \mathrm{C} .{ }^{1} \mathrm{H}$ NMR $(500 \mathrm{MHz}$, $\left.\mathrm{CDCl}_{3}\right): \delta 8.61(\mathrm{dd}, J=7.6,2,1.2 \mathrm{~Hz}, 2 \mathrm{H}), 8.54(\mathrm{~d}, J=8.4 \mathrm{~Hz}, 1 \mathrm{H}), 7.72$ $(\mathrm{t}, J=7.2,8.4 \mathrm{~Hz}, 1 \mathrm{H}), 7.05(\mathrm{~d}, J=8.4 \mathrm{~Hz}, 1 \mathrm{H}), 4.44(\mathrm{t}, J=4.4,4.8 \mathrm{~Hz}, 2 \mathrm{H})$, $4.18(\mathrm{t}, J=7.2,7.6 \mathrm{~Hz}, 2 \mathrm{H}), 3.95(\mathrm{t}, J=4.4,4.8 \mathrm{~Hz}, 2 \mathrm{H}), 3.54(\mathrm{~s}, 3 \mathrm{H}), 1.72(\mathrm{~m}$, $2 \mathrm{H}), 1.46(\mathrm{~m}, 2 \mathrm{H}), 0.98(\mathrm{t}, J=7.6,7.2 \mathrm{~Hz}, 3 \mathrm{H}) .{ }^{13} \mathrm{C} \mathrm{NMR}\left(\mathrm{CDCl}_{3}, 400 \mathrm{MHz}\right)$ 14.08, 20.63, 29.90, 40.31, 59.59, 68.60, 70.90, 106.15, 115.56, 122.68, 123.74, 126.12 , 128.94, 128.96, 129.61, 131.75, 133.47, 160.16, 164.15, 164.73. Ms: $\mathrm{m} / \mathrm{z}=327\left(\mathrm{M}^{+}, 95.47 \%\right)$. Elemental analysis for: $\mathrm{C}_{19} \mathrm{H}_{21} \mathrm{NO}_{4}$ Calc.: $\mathrm{C}, 69.71 ; \mathrm{H}$, 6.47; N, 4.28. Found: C, 69.50; H, 6.49; N, 4.26. 


\section{Results and discussion}

\section{Synthesis}

4-Alkoxy-1,8-naphthalimides have been obtained from naphthalimides substituted at the 4-position by electron-withdrawing groups by many procedures [3]. Most of the synthetic methods for preparation of 4-alkoxy-1,8-naphthalimides are based on nucleophilic aromatic substitution $\left(\mathrm{S}_{\mathrm{N}} \mathrm{Ar}\right)$ of halogens at the C-4 position by alkoxylating agents in dipolar aprotic solvents such as $\mathrm{N}$-methylpyrrolidinone, DMF, and quinoline [3, 4]. Catalysts such as potassium or copper acetates and phase-transfer catalysts are commonly used [3]. Some of these reactions are carried out under reflux at high pressures up to $10 \mathrm{~atm}$. The route to the synthesis of MEBN is presented in Scheme 1. MEBN was obtained by nucleophilic substitution of the bromide atom at the 4-position in 4-bromo- $N$-butyl-1,8-naphthalimide with a methoxyethoxy group under copper-catalyzed conditions and use the reactant 2-methoxyethanol itself as solvent. No phase-transfer catalyst is needed. In comparison with other literature procedures for synthesis of 4-alkoxy- $N$-substituted1,8-naphthalimides, our method has the advantages of employing simple and mild conditions, having an easy work-up, and giving excellent yields.

\section{Photophysical properties}

The UV-visible absorption of MEBN in $n$-hexane, toluene, $\mathrm{CHCl}_{3}$, and $\mathrm{CH}_{3} \mathrm{OH}$ was recorded to study its spectral properties in various solvents of different polarity (Fig. 1). The wavelengths corresponding to the spectral peaks are shown in Table 1. As indicated in the absorption spectra, MEBN has a common low-energy broad band at 350-360 nm. MEBN has structured absorption (there appear to be two shoulder peaks) in nonpolar solvents such as hexane, which could be ascribed to the lowest $\pi-\pi^{*}$ transitions $[4,5]$. On the other hand, bathochromic shifts in absorption due to solvent polarity were observed. For example, in hexane, MEBN had a $\lambda_{\max }$ value at $355 \mathrm{~nm}$ and a red-shift in absorbance for the polar solvent methanol at $365 \mathrm{~nm}$. It is interesting to compare the effect of the substituents at C-4 on the absorption spectrum. The absorption peak is observed at $355 \mathrm{~nm}$ for MEBN and $350 \mathrm{~nm}$ for 4-methoxy- $N$-butyl-1,8-naphthalimide (MBN) [4]. It can be seen that methoxyethoxy has stronger electron-donating ability than methoxy [4, 6-8].

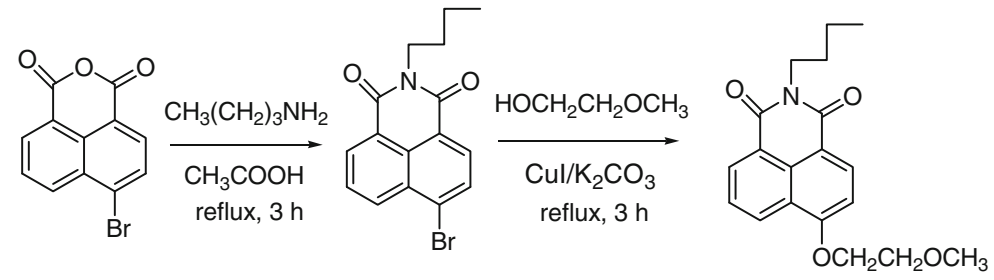

Scheme 1 Synthesis of MEBN 


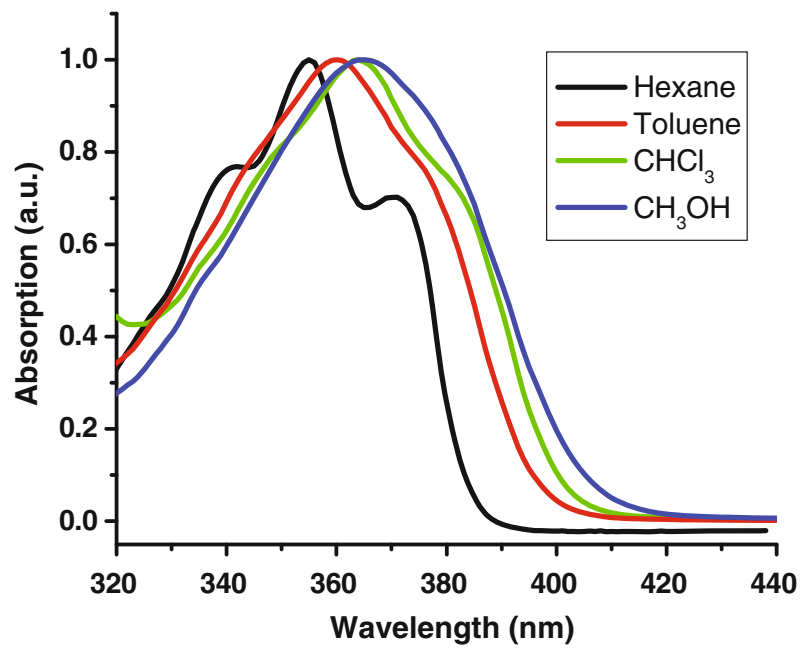

Fig. 1 Absorption spectra of MEBN in solvents of different polarity

Table 1 Absorption and fluorescence data for MEBN in solvents of different polarity

sh, shoulder

\begin{tabular}{lll}
\hline Solvent & $\begin{array}{l}\text { Absorption } \\
\text { maxima }(\mathrm{nm})\end{array}$ & $\begin{array}{l}\text { Emission } \\
\text { maxima (nm) }\end{array}$ \\
\hline$n$-Hexane & $342(\mathrm{sh}), 355,370(\mathrm{sh})$ & 406 \\
Toluene & 360 & 421 \\
$\mathrm{CHCl}_{3}$ & 364 & 426 \\
$\mathrm{CH}_{3} \mathrm{OH}$ & 365 & 448 \\
\hline
\end{tabular}

The fluorescence spectra of MEBN are displayed in Fig. 2. It can be observed from Fig. 2 that the fluorescence emission spectra of MEBN were also sensitive to solvent polarity. They move gradually to lower energies with increasing solvent polarity (Table 1). The effect of the polarity of the medium on the photoluminescent maximum was more pronounced than for the absorption maximum. The long wavelength of fluorescence emission observed in more polar solvents is undoubtedly due to an intramolecular charge-transfer transition. This observation demonstrates the highly polar nature of the $S_{1}$ excited state of MEBN $[9,10]$. Comparing MEBN and MBN, by changing the methoxy in MBN with 2-methoxyethoxy, the fluorescence emission maximum (in hexane) is increased by approximately $16 \mathrm{~nm}$. This behavior can be understood by taking into consideration the different electrondonating ability of the two substituents.

Cell imaging

To examine the potential of MEBN for imaging in cells, Hela cells were treated with $0.9 \%$ saline solution of MEBN $(500 \mu \mathrm{g} / \mathrm{mL}$, the cell culture medium was added also). The water solubility of MEBN is good. It was accordingly possible to directly 


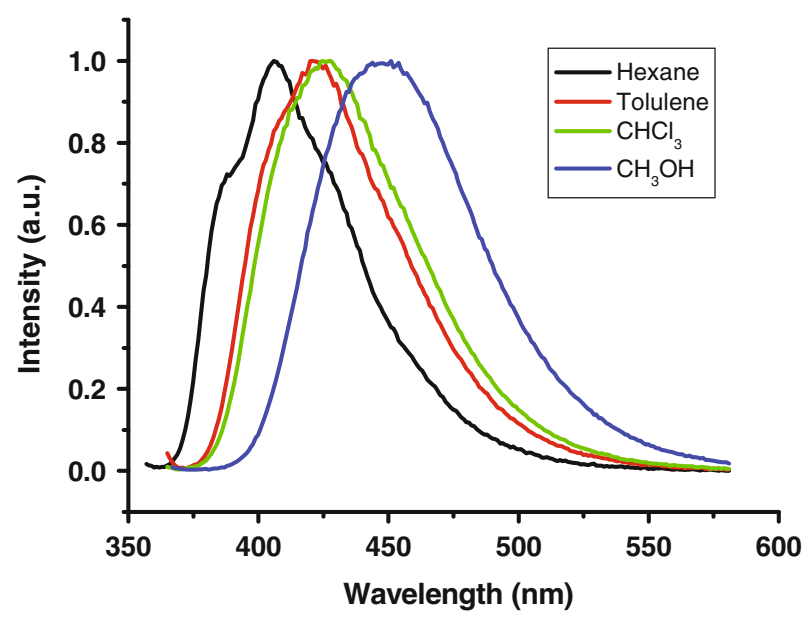

Fig. 2 Normalized fluorescence emission spectra of MEBN in solvents of different polarity
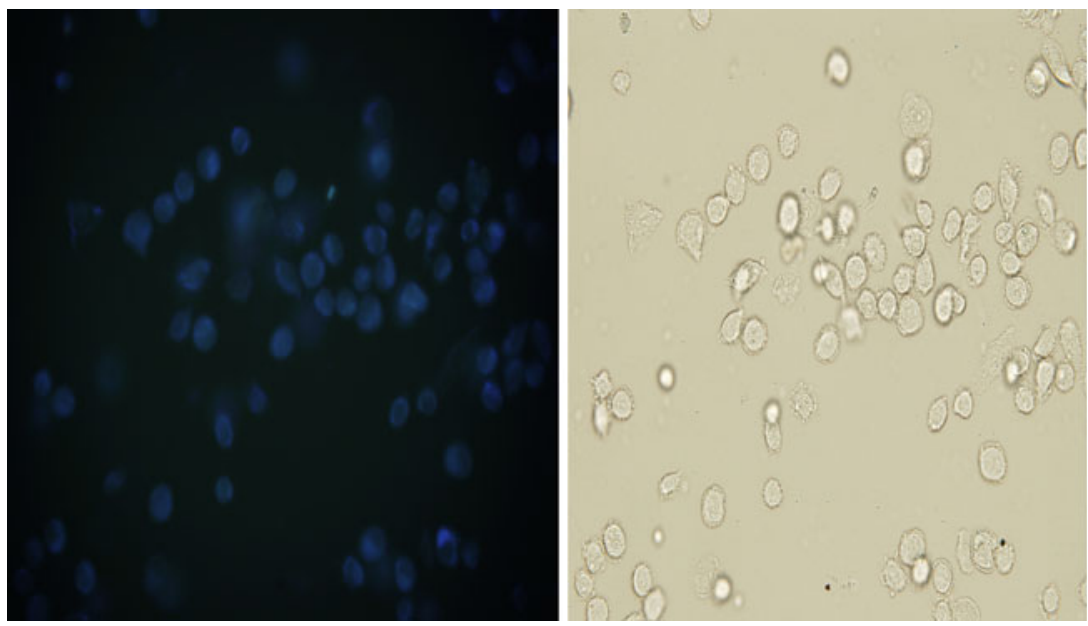

Fig. 3 Luminescence (left, $\lambda_{\mathrm{ex}}=365 \mathrm{~nm}$ ) and phase contrast (right) images of Hela cells

employ a $0.9 \%$ saline solution of the dye without use of any solubilizing agent such as CrEL (polyoxyethylene castor oil) [11]. Cells were incubated at room temperature for $2 \mathrm{~h}$ and were then washed with aqueous PBS solution to remove excess unbound dye. The slides were mounted and imaged by epifluorescence microscopy. The one-photon epifluorescence microscopy images are presented in Fig. 3. From Fig. 3, it is clear the dye had good permeability. After $48 \mathrm{~h}$ of incubation, $73.9 \%$ of cells are alive, which indicates that the toxicity of MEBN is low (In contrast, 100\% survival is observed for Hela cells not treated with MEBN [12].) 


\section{Conclusion}

A novel naphthalimide molecule, MEBN, was synthesized by use of a simple method. The absorption and photoluminescent spectra of MEBN in various solvents were investigated. Its optical properties depend on solvent polarity. By fluorescence cell imaging with MEBN, it was found that MEBN has good cell permeability, low toxicity, and has potential in cell imaging techniques.

Acknowledgments This work was financially supported by the Innovation Program of Shanghai Municipal Education Commission (no. 09YZ160).

Open Access This article is distributed under the terms of the Creative Commons Attribution Noncommercial License which permits any noncommercial use, distribution, and reproduction in any medium, provided the original author(s) and source are credited.

\section{References}

1. J. Wang, Y.M. Sun, X.L. Wang, Q. Wang, W.L. Xu, Dyes Pigm. 77, 125 (2008)

2. J.-X. Yang, X.-L. Wang, Tusong, L.-H. Xu, Dyes Pigm. 67, 27 (2005)

3. E.R. Triboni, R.G.S. Berlinck, M.J. Politi, P.B. Filho, J. Chem. Res. 2004, 508 (2004)

4. R. Badugu, J. Fluoresc. 15, 71 (2005)

5. B. Ramachandram, G. Saroja, N.B. Sankaran, A. Samanta, J. Phys. Chem. B 104, 11824 (2000)

6. S. Yao, K.J. Schafer-Hales, K.D. Belfield, Org. Lett. 9, 5645 (2007)

7. H.B. Xiao, L. Wang, X.M. Tao, M.J. Chen, Synth. Met. 160, 1313 (2010)

8. H.B. Xiao, H. Li, M.J. Chen, L. Wang, Dyes Pigm. 83, 334 (2009)

9. S. Wang, P.J. Zeng, Y.Q. Liu, G. Yu, X.B. Sun, H.B. Niu, D.B. Zhu, Synth. Met. 150, 33 (2005)

10. A. Jacobson, A. Petric, D. Hogenkamp, A. Sinur, J.R. Barrio, J. Am. Chem. Soc. 118, 5572 (1996)

11. L. Beverina, M. Crippa, M. Landenna, R. Ruffo, P. Salice, F. Silvestri, S. Versari, A. Villa, L. Ciaffoni, E. Collini, C. Ferrante, S. Bradamante, C.M. Mari, R. Bozio, G.A. Pagani, J. Am. Chem. Soc. 130, 1894 (2008)

12. D. Zheng, A. Bonoiu, T.Y. Ohulchanskyy, G.S. He, P.N. Prasad, Mol. Pharm. 5, 389 (2008) 